\title{
Identification of exon 19 and 21 mutations of EGFR gene in Chinese patients with esophageal squamous cell carcinoma
}

\author{
Yong Cui ${ }^{1}$, Dong Chang ${ }^{1}$, Mingliang Liu' ${ }^{1}$ Changjin Lin ${ }^{1}$, Baojian Zhao ${ }^{2}, X_{\text {X Zhang }}^{2}$ and Min Gong ${ }^{\text {** }}$
}

\begin{abstract}
Background: Although epidermal growth factor receptor (EGFR) inhibitor treatment showed modest response in several clinical trials in esophageal squamous cell carcinoma (ESCC) patients, it has been reported that the frequency of EGFR mutations varied largely. The aim of this study was to investigate the existence of EGFR mutations in Chinese esophageal squamous cell carcinomas.

Methods: Formalin-fixed paraffin-embedded surgically resected tumor samples were obtained from 127 randomly selected Chinese patients with ESCC. The most common EGFR mutations, including in-frame deletions in exon 19 and base substitutions in exon 21, were detected by denaturing high performance liquid chromatography (DHPLC) and direct sequencing simultaneously. K-RAS mutations in codons 12 and 13 were detected by direct sequencing.

Results: In this study, L858R missense mutations of the EGFR gene were found in 8 out of 127 patients (6.3\%) by DHPLC but no mutation was observed by direct sequencing. In addition, K-RAS mutation was detected in 2 out of 127 (1.6\%) patients by direct sequencing.

Conclusions: The incidence of EGFR mutations was relatively high using DHPLC method but no mutation with direct sequencing in Chinese ESCC patients.

Keywords: Epidermal growth factor receptor, Esophageal squamous cell carcinoma, Denaturing high performance liquid chromatography
\end{abstract}

\section{Background}

Esophageal squamous cell carcinoma (ESCC) is the major histological type of esophageal cancer and is one of the most aggressive malignant tumors in China [1]. Despite remarkable advances in multimodal therapies, patient prognosis remains poor, even for those whose carcinomas have been completely resected $[2,3]$. The limited improvement in treatment outcomes by conventional therapies urged us to seek innovative strategies for treating ESCC, especially those that are molecularly targeted. One of the most promising targets is the inhibition of the epidermal growth factor receptor (EGFR) by monoclonal antibodies (for example, cetuximab, panitumumab) or small molecule tyrosine kinase inhibitors (for example, erlotinib, gefitinib)

\footnotetext{
*Correspondence: guomin616616@163.com

'Department of Thoracic and Cardiovascular Surgery, Beijing Friendship

Hospital, Capital Medical University, Beijing 100050, China

Full list of author information is available at the end of the article
}

$[4,5]$. The EGFR is a member of the ErbB receptor tyrosine kinase family and plays an important role in cell cycle progression, angiogenesis, metastasis, and protection from apoptosis. Studies have showed that the kinase domain mutations of the EGFR gene in the non-small-cell lung cancer (NSCLC) tissues correlate with clinical responses to gefitinib. Most of the mutations were located in exons 19 and 21 of the EGFR gene including in-frame deletions in exon 19 and amino acid substitutions in exon 21 [4-6]. On the other hand, V-Ki-ras2 Kirsten rat sarcoma viral oncogene homolog (K-RAS) is a critical downstream effector of the EGFR pathway. K-RAS mutations are associated with intrinsic tyrosine kinase inhibitor (TKI) resistance in patients with lung cancer $[7,8]$. Thus, molecular diagnosis of these mutations is increasingly important in making therapeutic decisions.

Phase I and II clinical trials of the small-molecule TKIs of EGFR, erlotinib and gefitinib, in ESCC treatment are

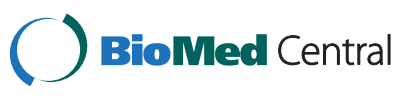

(c) 2013 Cui et al.; licensee BioMed Central Ltd. This is an open access article distributed under the terms of the Creative Commons Attribution License (http://creativecommons.org/licenses/by/2.0), which permits unrestricted use, distribution, and reproduction in any medium, provided the original work is properly cited. 
being carried out and modest activity has been observed in patients with esophageal cancers [9-11]. However, it remains unclear whether EGFR mutations in esophageal cancer predict benefits from treatment with EGFR inhibitors. Several studies have investigated the status of EGFR mutations in esophageal carcinoma and appear to suggest that EGFR mutations in esophageal carcinoma are rare but do exist [12-16]. Among these, one report carried out in Chinese patients found EGFR mutations in $14 \%$ of tumors, which is relatively higher than other regional research results. Furthermore, the authors used the scorpion amplification refractory mutation system (Scorpion-ARMS), a high sensitivity method for the identification of mutations. Therefore, it is worthwhile exploring whether different etiological factors or sensitivity methods contributed to the higher frequency of EGFR mutations in ESCC [16]. In this study, we investigated the existence of hot spot mutations in exon 19 and 21 of EGFR in Chinese ESCC patients with another sensitive method based on denaturing high performance liquid chromatography (DHPLC) as well as direct sequencing, simultaneously, and screened the status of $K-R A S$ gene (codon 12/13) mutation by direct sequencing as well.

\section{Methods}

\section{Patients}

A total of 127 consecutive patients with ESCC who were undergoing curative resection at Beijing Friendship Hospital of Capital Medical University between April 2008 and December 2011 were enrolled in this study. Tumor staging was done by the American Joint Committee on Cancer Staging Manual (7th edition). Written informed consent was obtained from each subject, and the study procedures were approved by the institutional review board of Capital Medical University.

\section{DNA extraction}

DNA was extracted from the tumor tissue sections $(5-\mu \mathrm{m}$ thickness) micro-dissected from formalin-fixed paraffinembedded tumor specimens. Genomic DNA was isolated by digestion with proteinase $\mathrm{K}$, followed by phenolchloroform extractions [17].

\section{PCR and DNA sequencing}

Three pairs of primers targeting exons 19 and 21 of the EGFR gene, as well as the K-RAS gene, were designed by using Primer Premier 5.0 (PREMIER Biosoft International, CA, USA). The sequences were as follows: exon 19: forward 5' - TGGTAACATCCACCCAGAT-3', reverse 5'CAGAGCAGCTGCCAGACATGAG-3'; exon 21: forward 5' - TACAGTGGATATAGAAAGGAC-3', reverse 5' - TGC TTATTTCATCTCAATCCTACGCTT-3'; K-RAS: forward 5' - CGCCGTTAACCTTATGTGTGACATGTTCTAA-3', reverse $5^{\prime}$ - CGCCGCTTTATCTGTATCAAAGAATGGT CCT-3'. PCR amplification was carried out on an ABI 9700 PCR thermal cycler (Applied Biosystems, Foster City, CA, USA) in a $50 \mathrm{uL}$ reaction system containing $1 \times$ buffer (10 mM Tris- $\mathrm{HCl}$ (pH 8.3), $1.5 \mathrm{mM} \mathrm{MgCl}_{2}, 50 \mathrm{mM}$ $\mathrm{KCl}$, and $0.1 \%$ gelatin $/ \mathrm{ml}$ ), $200 \mathrm{mM}$ each of the four deoxynucleotide triphosphates, $0.5 \mathrm{mM}$ of each primer, $5 \%$ DMSO (Sigma-Aldrich, St. Louis, MO, USA), 1 unit of Taq polymerase (Takara Bio, Hotsu, Japan) and 100 ng template. The PCR cycling conditions consisted of an initial denaturation step at $94^{\circ} \mathrm{C}$ for 5 minutes, followed by 35 cycles of $94^{\circ} \mathrm{C}$ for 30 seconds, $60^{\circ} \mathrm{C}$ for 30 seconds, $72^{\circ} \mathrm{C}$ for 30 seconds, and a final extension step at $72^{\circ} \mathrm{C}$ for 10 minutes. Reaction products were direct sequencing with an $\mathrm{ABI}$ PRISM 3100 sequencer (Applied Biosystems) following the manufacturer's protocol.

\section{Denaturing high performance liquid chromatography- based method for the detection of EGFR exon 19 and 21 mutations}

EGFR exon 19 deletion mutations were analyzed using DHPLC as described previously [18]. The most common mutation, L858R in exon 21 of EGFR, was detected using the restriction enzyme enriched mutation method as described except replacing polyacrylamide gel electrophoresis with DHPLC in the analyzing process [19]. Similar to Scorpion-ARMS, the detection sensitivity of the DHPLC method could reach approximately $1 \%$ mutant alleles $[18,19]$.

\section{Results}

EGFR exons 19 and 21 mutation in esophageal squamous cell carcinoma

No mutations in exons 19 and 21 of the EGFR were observed in the 127 patient tumor samples using direct sequencing analysis. However, a total of 8 samples out of 127 detected the same EGFR mutation (p.L858R) in exon 21 when DHPLC-based high sensitive methods were performed to detect EGFR mutations (Figure 1). No mutation was detected in exon 19 by either method.

\section{$K$-RAS mutation in esophageal squamous cell carcinoma}

A heterozygous mutation of the $K-R A S$ gene (c. $35 \mathrm{G}>\mathrm{T}$; p.Gly12Cys) was detected in 2 out of the 127 patients $(1.6 \%)$ by sequencing analysis (Figure 2 ), despite low level mutations. No mutation was found in codon 13.

\section{Discussion}

In NSCLC, a growing number of studies demonstrated that patients with EGFR mutations, mainly deletions in exon 19 and L858R mutation in exon 21, would benefit from EGFR-TKI treatment, particularly among those of Asian ethnicity $[5,18,20]$. Furthermore, a few clinical studies of advanced esophageal cancer treatment by gefitinib 


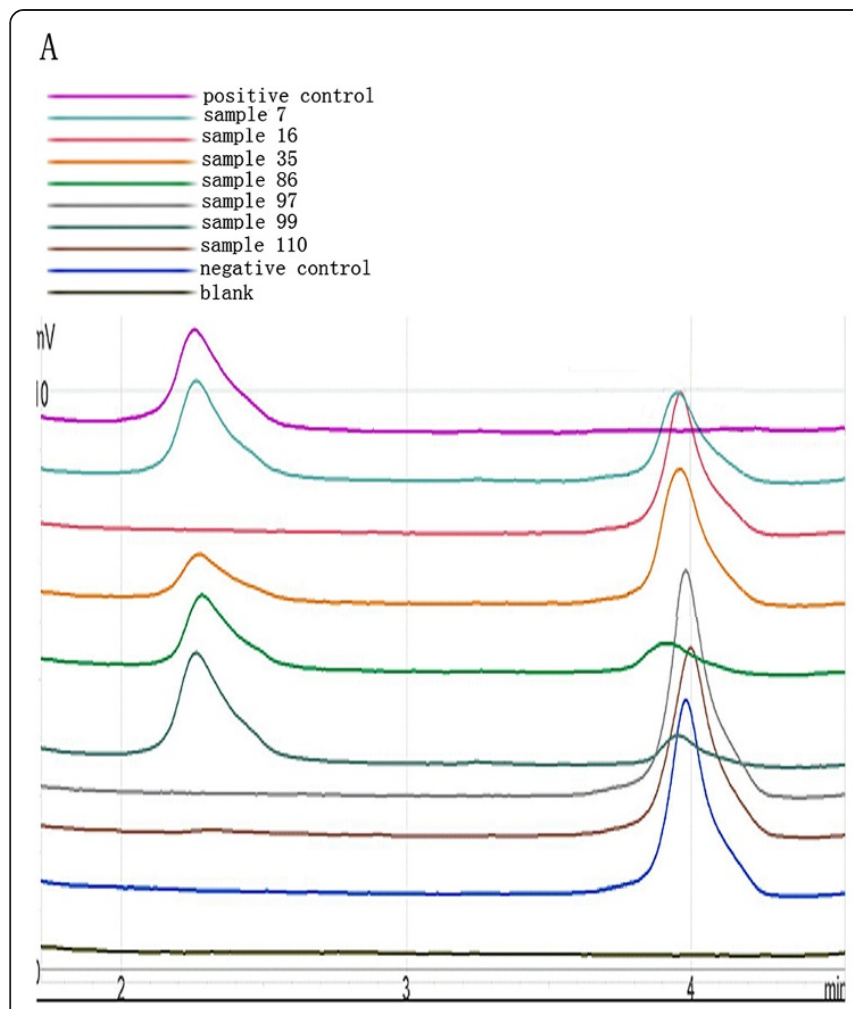

$\mathrm{B}$

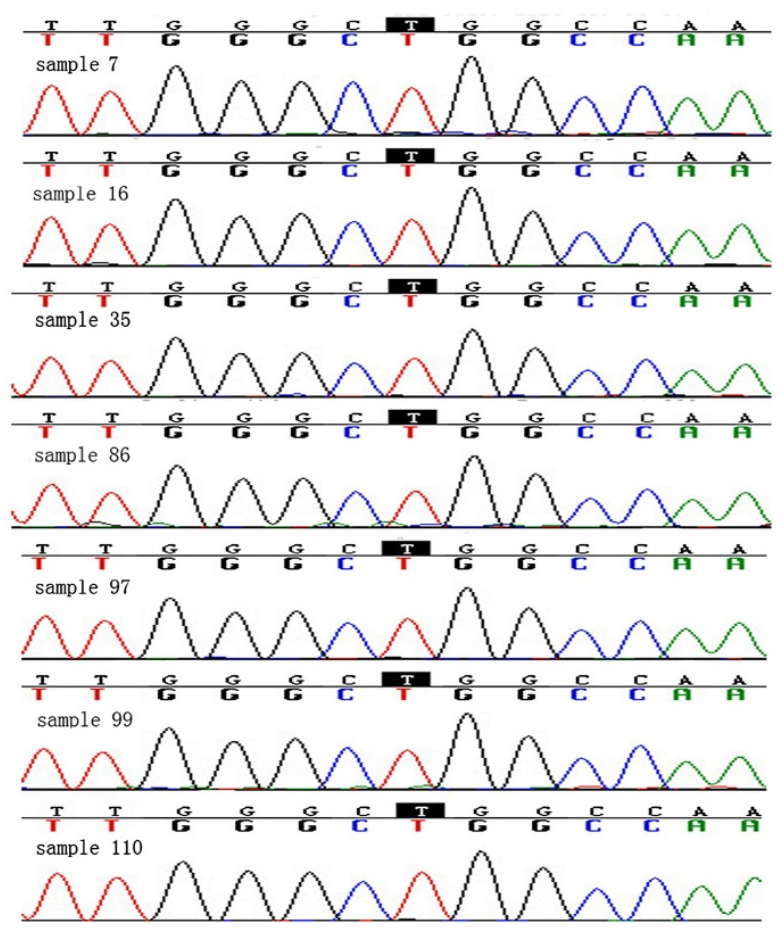

Figure 1 Representative result of denaturing high performance liquid chromatography and sequencing for EGFR L858R mutations.

(A) L858R missense mutations in exon 21 were found using the denaturing high performance liquid chromatography-based method. A single peak on the left (123 bp) indicates mutant alleles, and that on the right indicates wild-type alleles at about $138 \mathrm{bp}$. (B) No mutations were detected under sequencing conditions.

showed moderate responses $[9,11,21]$. However, several studies have investigated the status of EGFR mutations in esophageal carcinoma and they mostly showed a very low frequency of EGFR-activating mutations [12-16,22-24]. It should be noted that EGFR mutations were detected by a high sensitive method instead of direct sequencing only in a few studies, and one of them reported relatively higher frequency of EGFR mutations in 14\% of tumors including G719X missense mutation $(\mathrm{n}=1)$, in-frame deletion $(\mathrm{n}=$ 2), and L858R missense mutation $(n=5)$ [16].

In this study, a high sensitivity DHPLC-based method, as well as conventional direct sequencing, were performed

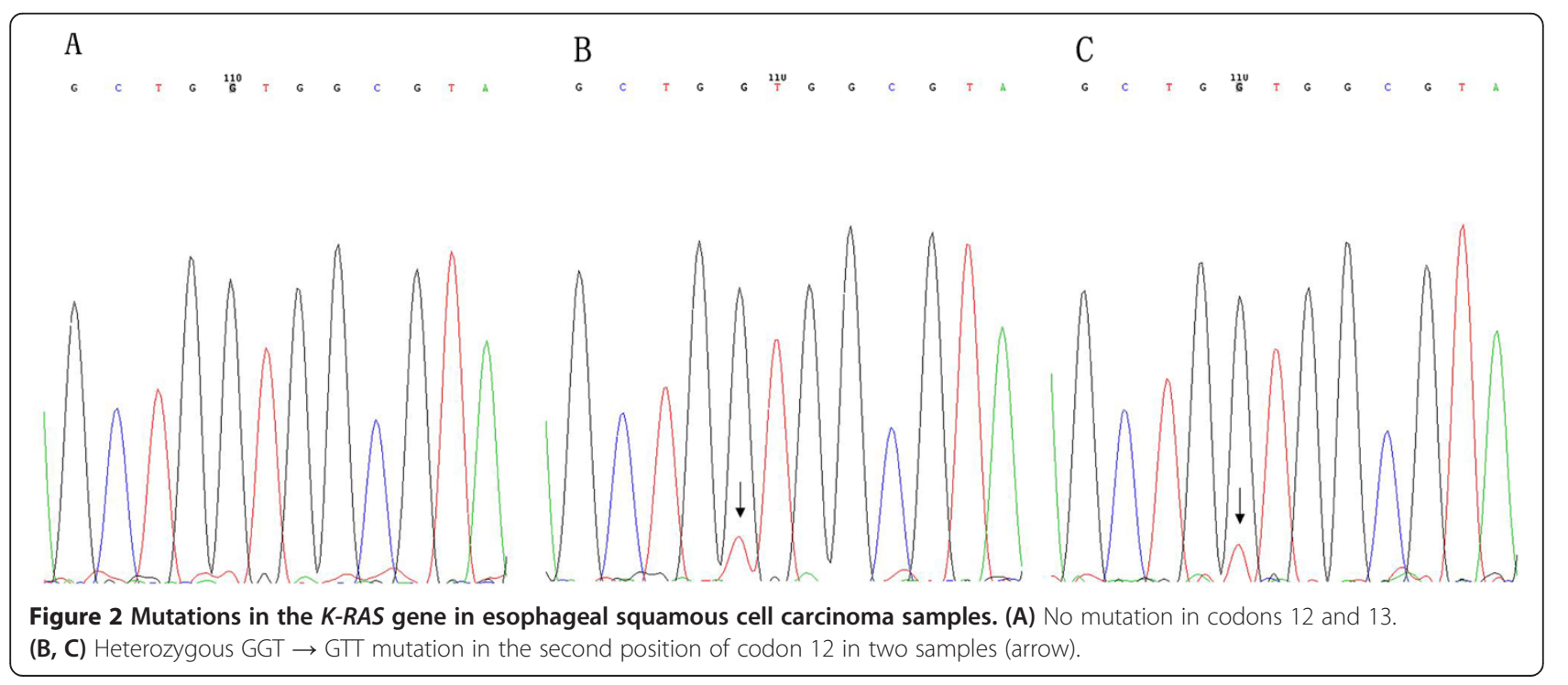


to screen deletions in exon 19 and L858R mutation in exon 21 of the EGFR gene in 127 Chinese ESCC patients, respectively. The results showed that $7 \%$ of the ESCC samples harbored EGFR mutations detected by DHPLC compared with no observed EGFR mutation by direct sequencing, which may be partly attributed to the high sensitivity of DHPLC in mutation detection. Our findings were consistent with a previous study in which ScorpionARMS, another high sensitivity method to detect EGFR mutation, was performed to screen EGFR mutation in Chinese ESCC patients [16]. Furthermore, the status of KRAS gene mutationwas detected by direct sequencing and showed relatively low frequency (1.6\%); this was in line with previous studies in which the incidence of $K-R A S$ gene mutations ranges between 0 and $16 \%[16,25,26]$. Together with other findings, our data indicated that EGFR mutations exist in esophageal carcinoma at low levels, which is difficult to detect by conventional DNA sequencing. This partly explains the variant frequency of EGFR mutations in several studies with different sensitivity methods and complicates the efficacy of targeted therapies in some patients except for etiological factors [13,16,22]. The existence of low levels of EGFR mutation in ESCC indicates the presence of intra-tumor EGFR mutational heterogeneity, suggesting high sensitivity method should be preferred for studies exploring the correlation between EGFR mutations and TKI treatment in ESCC patients.

\section{Conclusion}

Our findings demonstrated that the incidence of EGFR mutations in Chinese patients with ESCC was relatively higher than that of previous reports, partly as a result of mutation detection with a high sensitivity method. In line with other studies, it seemed that a high sensitivity method should be preferred when the status of EGFR mutations need to be explored in clinical trials of TKI in ESCC treatment.

\begin{abstract}
Abbreviations
DHPLC: Denaturing high performance liquid chromatography;

EGFR: Epidermal growth factor receptor; ESCC: Esophageal squamous cell carcinoma; NSCLC: Non-small-cell lung cancer; PCR: Polymerase chain reaction; Scorpion-ARMS: Scorpion amplification refractory mutation system; TKl: Tyrosine kinase inhibitor.
\end{abstract}

\section{Competing interests}

The authors declare that they have no competing interests.

\section{Authors' contributions}

MG drafted and finalised writing of the manuscript. YC and DC carried out the molecular genetic studies. BZ and XZ performed DHPLC analysis, ML and $\mathrm{CL}$ analysed the data. All authors read and approved the final manuscript.

\section{Acknowledgments}

This work was supported in part by the following grants: Nature Science Foundation of Beijing 2010 (№. 7102042).

\section{Author details}

'Department of Thoracic and Cardiovascular Surgery, Beijing Friendship Hospital, Capital Medical University, Beijing 100050, China. ${ }^{2}$ Molecular Pathology Center, The General Hospital of The Air Force P.L.A, Beijing 100087, China.

Received: 14 March 2013 Accepted: 22 September 2013 Published: 9 October 2013

\section{References}

1. Zhang J, Dhakal IB, Zhao Z, Li L: Trends in mortality from cancers of the breast, colon, prostate, esophagus, and stomach in East Asia: role of nutrition transition. Eur J Cancer Prev 2012, 21:480-489.

2. Jin J, Xu X, Wang F, Yan G, Liu J, Lu W, Li X, Tucker SJ, Zhong B, Cao Z, Wang D: Second-line combination chemotherapy with docetaxel and nedaplatin for cisplatin-pretreated refractory metastatic/recurrent esophageal squamous cell carcinoma. J Thorac Oncol 2009, 4:1017-1021.

3. Park BB, Im YH, Hwang IG, Lee SC, Ahn JS, Ahn MJ, Lim HY, Kang WK, Park K: Salvage chemotherapy with mitomycin C, ifosfamide, and cisplatin (MIC) for previously treated metastatic or recurrent esophageal squamous cell carcinoma. Invest New Drugs 2008, 26:387-392.

4. Lynch TJ, Bell DW, Sordella R, Gurubhagavatula S, Okimoto RA, Brannigan BW, Harris PL, Haserlat SM, Supko JG, Haluska FG, Louis DN, Christiani DC, Settleman J, Haber DA: Activating mutations in the epidermal growth factor receptor underlying responsiveness of non-small-cell lung cancer to gefitinib. N Engl J Med 2004, 350:2129-2139.

5. Zhang GC, Lin JY, Wang Z, Zhou Q, Xu CR, Zhu JQ, Wang K, Yang XN, Chen G, Yang JJ, Huang YJ, Liao RQ, Wu YL: Epidermal growth factor receptor double activating mutations involving both exons 19 and 21 exist in Chinese non-small cell lung cancer patients. Clin Oncol (R Coll Radiol) 2007, 19:499-506.

6. Welsh JW, Komaki R, Amini A, Munsell MF, Unger W, Allen PK, Chang JY, Wefel JS, McGovern SL, Garland LL, Chen SS, Holt J, Liao Z, Brown P, Sulman E, Heymach JV, Kim ES, Stea B: Phase II trial of erlotinib plus concurrent whole-brain radiation therapy for patients with brain metastases from non-small-cell lung cancer. J Clin Oncol 2013.

7. Zhu CQ, Da Cunha Santos G, Ding K, Sakurada A, Cutz JC, Liu N, Zhang T, Marrano P, Whitehead M, Squire JA, Kamel-Reid S, Seymour L, Shepherd FA, Tsao MS, National Cancer Institute of Canada Clinical Trials Group Study BR.21: Role of KRAS and EGFR as biomarkers of response to erlotinib in National Cancer Institute of Canada Clinical Trials Group Study BR.21. J Clin Oncol 2008, 26:4268-4275.

8. Finberg KE, Sequist LV, Joshi VA, Muzikansky A, Miller JM, Han M, Beheshti J, Chirieac LR, Mark EJ, lafrate AJ: Mucinous differentiation correlates with absence of EGFR mutation and presence of KRAS mutation in lung adenocarcinomas with bronchioloalveolar features. J Mol Diagn 2007, 9:320-326.

9. Rodriguez CP, Adelstein DJ, Rice TW, Rybicki LA, Videtic GM, Saxton JP, Murthy SC, Mason DP, Ives DI: A phase II study of perioperative concurrent chemotherapy, gefitinib, and hyperfractionated radiation followed by maintenance gefitinib in locoregionally advanced esophagus and gastroesophageal junction cancer. J Thorac Oncol 2010, 5:229-235.

10. Ramos-Suzarte M, Lorenzo-Luaces P, Lazo NG, Perez ML, Soriano JL, Gonzalez CE, Hernadez IM, Albuerne YA, Moreno BP, Alvarez ES, Callejo IP, Alert J, Martell JA, Gonzalez YS, Gonzalez YS, Astudillo de la Vega H, RuizGarcia EB, Ramos TC: Treatment of malignant, non-resectable, epithelial origin esophageal tumours with the humanized anti-epidermal growth factor antibody nimotuzumab combined with radiation therapy and chemotherapy. Cancer Biol Ther 2012, 13:600-605.

11. Xu Y, Sheng L, Mao W: Role of epidermal growth factor receptor tyrosine kinase inhibitors in the treatment of esophageal carcinoma and the suggested mechanisms of action. Oncol Lett 2013, 5:19-24.

12. Puhringer-Oppermann FA, Stein HJ, Sarbia M: Lack of EGFR gene mutations in exons 19 and 21 in esophageal (Barrett's) adenocarcinomas. Dis Esophagus 2007, 20:9-11.

13. Sudo T, Mimori K, Nagahara H, Utsunomiya T, Fujita H, Tanaka Y, Shirouzu K, Inoue $\mathrm{H}$, Mori M: Identification of EGFR mutations in esophageal cancer. Eur J Surg Oncol 2007, 33:44-48.

14. Mir MM, Dar NA, Salam I, Shah ZA: Mutations in epidermal growth factor receptor gene in esophageal squamous cell carcinoma patients in 
Kashmir- a high incidence area of India. Int J Health Sci (Qassim) 2008, 2:17-25.

15. Kaneko K, Kumekawa Y, Makino R, Nozawa H, Hirayama Y, Kogo M, Konishi K, Katagiri A, Kubota Y, Muramoto T, Kushima M, Ohmori T, Oyama T, Kagawa N, Ohtsu A, Imawari M: EGFR gene alterations as a prognostic biomarker in advanced esophageal squamous cell carcinoma. Front Biosci 2010, 15:65-72.

16. Liu QW, Fu JH, Luo KJ, Yang HX, Wang JY, Hu Y, Yang H, Bella E: Identification of EGFR and KRAS mutations in Chinese patients with esophageal squamous cell carcinoma. Dis Esophagus 2011.

17. Blin N, Stafford DW: A general method for isolation of high molecular weight DNA from eukaryotes. Nucleic Acids Res 1976, 3:2303-2308.

18. Bai H, Mao L, Wang HS, Zhao J, Yang L, An TT, Wang X, Duan CJ, Wu NM, Guo ZQ, Liu YX, Liu HN, Wang YY, Wang J: Epidermal growth factor receptor mutations in plasma DNA samples predict tumor response in Chinese patients with stages IIIB to IV non-small-cell lung cancer. J Clin Oncol 2009, 27:2653-2659.

19. Asano H, Toyooka S, Tokumo M, Ichimura K, Aoe K, Ito S, Tsukuda K, Ouchida M, Aoe M, Katayama H, Hiraki A, Sugi K, Kiura K, Date H, Shimizu N: Detection of EGFR gene mutation in lung cancer by mutant-enriched polymerase chain reaction assay. Clin Cancer Res 2006, 12:43-48.

20. Moore MJ, Goldstein D, Hamm J, Figer A, Hecht JR, Gallinger S, Au HJ, Murawa P, Walde D, Wolff RA, Campos D, Lim R, Ding K, Clark G, VoskoglouNomikos T, Ptasynski M, Parulekar W, National Cancer Institute of Canada Clinical Trials Group: Erlotinib plus gemcitabine compared with gemcitabine alone in patients with advanced pancreatic cancer: a phase III trial of the National Cancer Institute of Canada Clinical Trials Group. J Clin Oncol 2007, 25:1960-1966.

21. Janmaat ML, Gallegos-Ruiz MI, Rodriguez JA, Meijer GA, Vervenne WL, Richel DJ, Van Groeningen C, Giaccone G: Predictive factors for outcome in a phase II study of gefitinib in second-line treatment of advanced esophageal cancer patients. J Clin Oncol 2006, 24:1612-1619.

22. Wang WP, Wang KN, Gao Q, Chen LQ: Lack of EGFR mutations benefiting gefitinib treatment in adenocarcinoma of esophagogastric junction. World I Surg Oncol 2012, 10:14

23. Tasioudi KE, Saetta AA, Sakellariou S, Levidou G, Michalopoulos NV, Theodorou D, Patsouris E, Korkolopoulou P: pERK activation in esophageal carcinomas: clinicopathological associations. Pathol Res Pract 2012, 208:398-404.

24. Gonzaga IM, Soares-Lima SC, de Santos PT, Blanco TC, de Reis BS, Quintella DC, de Oliveira IM, de Faria PA, Kruel CD, Andreollo NA, de Simão TA, Pinto LF: Alterations in epidermal growth factor receptors 1 and 2 in esophageal squamous cell carcinomas. BMC Cancer 2012, 12:569.

25. Lyronis ID, Baritaki S, Bizakis I, Krambovitis E, Spandidos DA: K-ras mutation, HPV infection and smoking or alcohol abuse positively correlate with esophageal squamous carcinoma. Pathol Oncol Res 2008, 14:267-273.

26. Shigaki H, Baba Y, Watanabe M, Miyake K, Murata A, Iwagami S, Ishimoto T, Iwatsuki M, Yoshida N, Baba H: KRAS and BRAF mutations in 203 esophageal squamous cell carcinomas: pyrosequencing technology and literature review. Ann Surg Oncol 2012.

doi:10.1186/1477-7819-11-266

Cite this article as: Cui et al: Identification of exon 19 and 21 mutations of EGFR gene in Chinese patients with esophageal squamous cell carcinoma. World Journal of Surgical Oncology 2013 11:266.

\section{Submit your next manuscript to BioMed Central and take full advantage of:}

- Convenient online submission

- Thorough peer review

- No space constraints or color figure charges

- Immediate publication on acceptance

- Inclusion in PubMed, CAS, Scopus and Google Scholar

- Research which is freely available for redistribution

Submit your manuscript at www.biomedcentral.com/submit
C Biomed Central 